"Started from Christiania at about 2 a.m. in the Nyland steamer bound for Christiansand. At Krujero the steamer forced its way through the ice for half an hour till within about a mile of the land, where sleighs met it on the ice. The passengers and cargo were discharged or taken up on the ice, out of which we backed in close proximity to the Kong Hacon, which steamer had followed us in. A beautiful sunset and Arctic winter view, clear air, and rich sky, also a distant ship fast in the ice. The Nyland stopped at Arendal for the night, having got to the quay through much ice. We observe of ten phosphoresce ce or phosphorescence-like sparks and flashes in the ice as it is broken up by the steamer."

I think that the average thickness of the ice might have been about eight inches. I cannot give the temperature, but on the previous day at Christiania the thermometer indicated about $8^{\circ}$ or $10^{\circ}$ below zero Fabrenheit (about $40^{\circ}$ Fahrenheit of frost). The diary from which the above extract is taken was kef, jointly by myself and my travelling-companion, $\mathrm{Mr}$. Winter, of the Indian Civil Service, who of course also saw the flashes referred to. I should like to have been able to talk the matter over again with him, but he is now in India. J. AlLEN AlLEN

[The question raised in this letter is a very interesting one. The phenomenon is possibly analogous to the electric flashes which are produced when loaf-sugar is crushed or when mica is rapidly split. It appears very improbable that it can be due to phosphorescent creatures in the water under the ice.-ED.]

\section{Tidal Currents versus Wind Waves}

In NATURE, vol. xxiv, p. 286, a writer on "sea-shore alluvion" positively asserts that the travelling of sea beaches is due to wind-waves, and not to tidal currents, and calls a writer in the Engineer to task for laving stated the latter. Notwithstanding this assertion, I would suggest that the writer in the Engineer is right. Twenty-five years ago, when an engineering student, I was taught that sea-beach travelling was due to wind-waves. Afterwards, whi'e l nocking about during fifteen years in the vicinity of the south and west coasts of Ireland, I noted facts that went to show that such a theory was not universally correct. This led me to study wind-action on the sea and lakes, also all I could find that had been written on the subject; the result being that as cood evidence was so contradictory, no opinion conld be come to from the evidence of others. But it was not till about ten years ago, when I was so circumstanced that I could properly study wave-action, and after six years' careful observation on the south-east coast of 'reland, that I found that tidal currents were the principal motive power; and on again reading what had been written on the suhject, that I found that nearly all the advocates for the driftage of sea beaches by wind-waves had stadied on beaches where the most continuous and powerful winds acted in conjunction with the flow-tide current. As the results of my observations have been published in the Proceedings of the Royal Irish Academy, English and Irish Institutions of Civil Engineers, the Geological Societies of London, Dublin, \&c., during the last six or eight years, it is unnecessary to repeat them here. I would, however, point out that when there are only wind-waves and no tidal currents, the beaches as a general rule re banked up, but do not travel (the writer in NATURE seems to have observed this, but does not appear to see the importance of it). This may be seen in the tideless Mediterranean, as pointed out by the late Dr. Ansted in his paper on the Lagoons at the Delta of the Rhone; it may also be seen in Malcombe, or any other bay where there is a "head of the tide" but no tidal current; and in the different freshwater lakes, when the wind-waves are the only motive power. But wherever there are tidal currents acting on a coast the beach must travel. Such tidal currents are those that most perplex the erectors of groynes. If there was only the travelling augmented by wind-waves, the erection of groynes would be very simple; but, as a general rule, they are most necessary where there are strong tidal currents (or conflicting currents) due to the regular "flow" tide, "half c)unter" tides, or "on-shore" tides; which conflicting currents, combined with the action of wind-waves, let them be direct or as "ground swells," make up all the "cutting-out tides." The greater the complications the greater the "cutting out," and the more ingenious have to be the groynes. "Fulls" accumulate with the wind-waves, but rapidly disappear when the wind ceases. I presume the writer of the article in question is aware that the greatest rise of tide and the least current is at the "heads of the tides," while the least rise and greatest current is at the "nodal or hinge lines"; and I would be interested to know where permanent beaches accumulate in the latter localities, as from what I have seen those that form rapidly disappear when the wind ceases. G. H. KINAHAN

H.M. Geological Survey

\section{Glaciation}

In NATURE, vol. xxiv. p. 364 , I see a notice of a paper by Dr. Woeikoff on the glacial climate, in which it is shown that "the difference of min temperature at the lower ends of glaciers (in different parts of the world) reaches fully $20^{\circ}$." This might be expected. The extent of glaciation depends not at all on mean or on winter temperature, but cliefly on summer temfe. rature. Perpetual snow means summer snow, so that summer temperature is what determines the extent of the snow-fields remaining unmelted in the summer, and consequently of the glaciers which are fed by the snow-fields. The extent of glaciation is also much influenced by the amount of snow-fall. All this is stated in Forbes's "Norway and its Glaciers."

Old Forge, Dunmurry, Co. Antrim JOSEPH JOHN MURPHY

\section{Yellow Glass in Fog}

SOME years ago I was staying at an hotel on the Lake of Constance. One morning a fog came on which completely obscured the opposite shore, but looking through a strip of yellow glass, which formed the border of the window, I was able, to my surprise, to see it distinctly. I presume the yellow glass choked the blue rays reflected by the fog, just as a Nicol's prism, held at the proper angle, chokes the rays reflected from the glass and enables us to see clearly the picture behind it. Cn my way home I stopped in Paris, and, happening to call on one of the principal opticians, mentioned the circumstance to him. He forthwith showed me a naval telescope providea with a cap at the eye end containing a yellow glass, which could be removed at pleasure, I should like to know if the same simple contrivance has ever been used in our own navy.

$\mathrm{R}$.

\section{The New Museum of Natural History}

IN your article on "The New Museum of Natural History" (NATURE, vol. xxiii. p. 549 et seq.) it is stated that the specimen of Archaopteryx macrura in the British Museum is headless. Will you permit me to draw attention to a nodule projecting from the slab in which the fossil lies, which bears a striking resemblance to the cerebral portion of a bird's skull? It is some years since I visited the museum, but I recollect feeling satisfied at the time that the nodule was the missing head, and worth while disinterring from its surrounding slate. E. H. PRINGLE

\section{Calicut, July $3 \mathbf{I}$}

[The nodule referred to by our correspondent is well known, and has been frequently criticised. Mr. John Evans, D.C.L. F.R.S., drew attention to it in an article published by him in the Natural History Review, 1865, pp. 415.421 : "On portions of a cranium and of a jaw in the slab containing the fossil remains of the Archaopteryx." Although these fragments which occur in the slab in question undoubtedly belong to Archao. pteryx, yet, as stated in our article, vol. xxiii. p. 551, "The original specimen described by Prof. Owen is headless," whereas the newly-discovered Berlin specimen has the head entire, and fairly well preserved, and still attached by the neck to the trunk.-ED.]

\section{On the Velocity of Light}

IN view of the experiments of Young and Forbes on the velocity of light, and of the article published by Lord Rayleigh on the subject, it may not be out of place to state as a fact which seemed at the time too evident to require special mention in my paper "On the Velocity of Light," that if the velocity of red and of blue light in air differed by as much as one-tenth of I per cent., the image of the slit which served as the source of light, instead of being white, would be spread out into a spec. tram which could not fail to be observed. The total displacement in these experiments amounted to 133 millimetres; therefore, a difference of velocity of the red and the blue rays of 1.8 per cent. would necessitate a spectrum 2.4 millimetres in length. 